\title{
A Case of Advanced Multiple Hepatocellular Carcinomas with Portal Vein Tumor Thrombosis Successfully Treated by Oral Tegafur/Uracil
}

\author{
Hiroto Tanaka ${ }^{1}$, Huuta Koga ${ }^{1}$, Masako Hasegawa ${ }^{1}$, Hiroshi Takihara ${ }^{1}$, Eri Kimura ${ }^{1}$, Tarou Inoue ${ }^{1}$, \\ Chie Ueda ${ }^{1}$, Wataru Ono ${ }^{1}$, Seigou Takamatsu ${ }^{1}$, Yasushi Nakamura ${ }^{2}$, Hiroki Ueda ${ }^{3}$ \\ ${ }^{1}$ The Department of Gastroenterology, Kishiwada Tokushukai Hospital, Osaka, Japan; ${ }^{2}$ The Department of Internal Medicine, Kainan \\ Hospital, Wakayama, Japan; ${ }^{3}$ The Third Department of Internal Medicine, Wakayama Medical University, Wakayama, Japan. \\ Email: hgvttv1@r5.dion.ne.jp
}

Received May $18^{\text {th }}, 2010$; revised June $2^{\text {nd }}, 2010$; accepted July $10^{\text {th }}, 2010$.

\begin{abstract}
A case of advanced multiple hepatocellular carcinomas (HCC) with portal vein tumor thrombosis successfully treated by oral tegafur/uracil is reported. A 69-year-old Japanese woman with advanced HCC with tumor thrombosis underwent transcatheter arterial infusion chemotherapy in April 2001. However, 1 year later, the patient experieced a recurrence with advanced multiple HCC with portal vein tumor thrombosis and ascites. Treatment with oral tegafur/uracil was started in May 2002 and resulted in the partial response of liver tumors and the complete improvement of ascites. She remained in good health for about 6 years. This case strongly suggests that oral tegafur/uracil is an effective treatment for some cases of advanced HCC with portal vein tumor thrombosis.
\end{abstract}

Keywords: Advanced Hepatocellular Carcinoma, Portal Vein Thrombosis, Oral Tegafur/Uracil, Chemotherapy

\section{Introduction}

Various treatment modalities, such as transcatheter arterial chemoembolization (TACE), percutaneous ethanol injection therapy (PEIT), and radiofrequency ablation (RFA) have been recently developed and are used worldwide to treat patients with hepatocellular carcinoma (HCC) [1-4]. However, the use of these modalities for advanced HCC is limited.

On the other hand, it has been reported that patients with multiple HCCs with tumor thrombosis in the major portal branches were successfully treated with intraarterial 5-fluorouracil perfusion chemotherapy combined with subcutaneous interferon-alpha administration $[5,6]$. Such combination therapy may be a promising treatment modality for advanced HCC with tumor thrombosis. However, the prognosis of advanced HCC with tumor thrombosis (VP4) is still unsatisfactory. A rare case of advanced multiple HCCs with portal vein thrombosis (VP4) that was successfully treated by oral tegafur/uracil (UFT $^{\circledR}$, Taiho Pharmaceutical Co. Ltd. Tokyo, Japan) and had a good prognosis, with survival for more than 5 years, is reported.

\section{Case Presentation}

A 69-year-old woman with advanced HCC with tumor thrombosis underwent transcatheter arterial infusion chemotherapy in April 2001. However, 1 year later, the patient experienced advanced multiple HCCs with portal vein thrombosis (VP4) and ascites (Figure 1). As shown in Table 1, the patient had decompensated liver cirrhosis due to hepatitis $\mathrm{C}$ virus. On admission, the alpha-fetoprotein (AFP) level was $317.2 \mathrm{ng} / \mathrm{ml}$, and the level of tumor marker known as protein-induced vitamin $\mathrm{K}$ antagonist II (PIVKA-II) was 162,210 $\mathrm{mAU} / \mathrm{ml}$. Treatment, such as TACE, PEIT, or RFA, was not administered. She was treated with oral UFT ${ }^{\circledR}$ in May 2002. This treatment resulted in the partial response of liver tumors and the complete improvement of ascites (Figure 2). At the same time, the AFP level was $303.9 \mathrm{ng} / \mathrm{ml}$ and the PIVKA-II level was $468 \mathrm{mAU} / \mathrm{ml}$.

In January 2005, the AFP level was $93.7 \mathrm{ng} / \mathrm{ml}$ and the PIVKA-II level was $38 \mathrm{mAU} / \mathrm{ml}$. The patient then experienced recurrent tumors in liver segment five, for which TACE was performed each time.

The patient remained in good health for about 6 years. 
In July 2008, acute peritonitis developed due to tumor invasion into the duodenum and the patient died.

\section{Discussion}

Several treatments, such as TACE, PEIT, RFA, and hepatic resection, have been established as effective and safe therapeutic modalities for HCC $[7,8]$. However, frequent $\mathrm{HCC}$ recurrence, even after curative treatment, and advanced stages of HCC, such as in cases with portal invasion, remain major clinical problems.
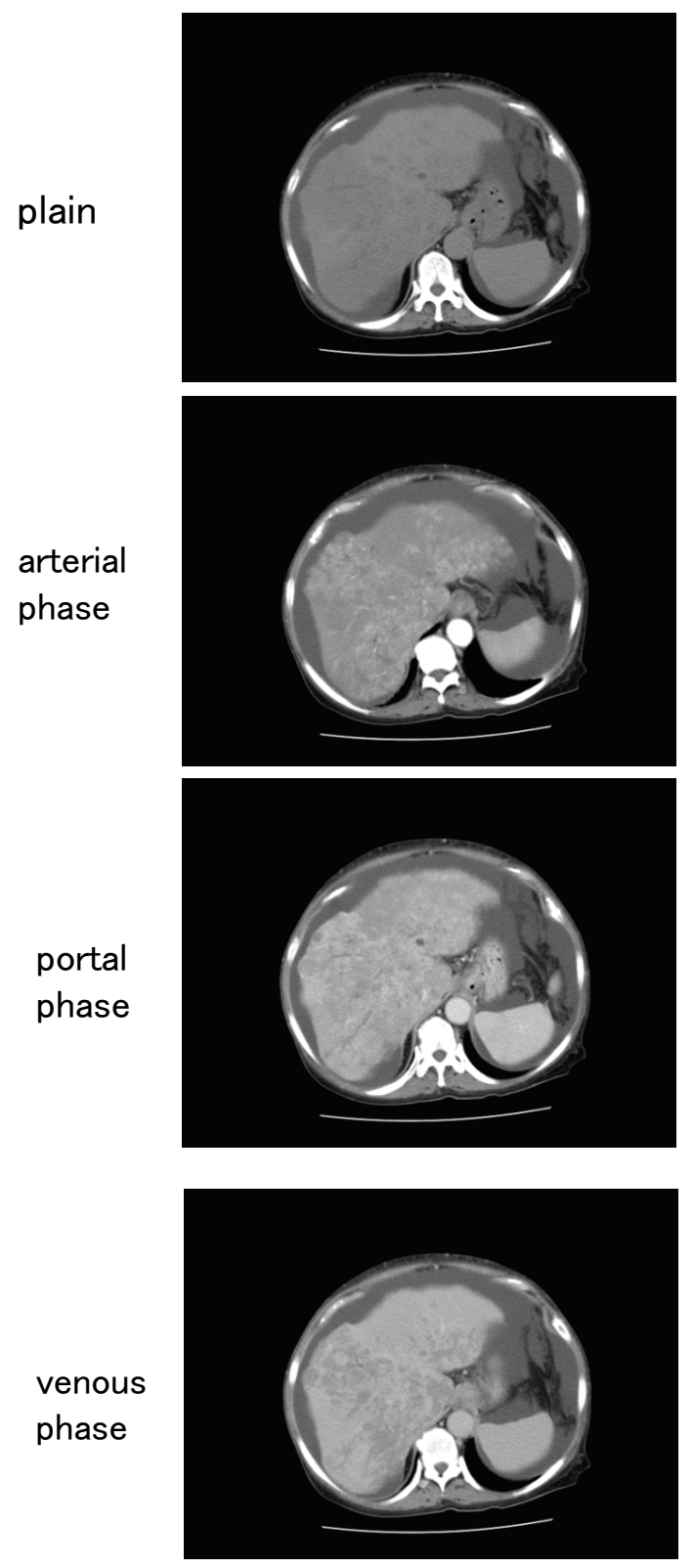

The product $\mathrm{UFT}^{\circledR}$ combines tegafur, a prodrug of 5-fluorouracil, with uracil, a biomedical modulator, in a molar ratio of $4: 1$. $\mathrm{UFT}^{\circledR}$ has been reported to be effective against colorectal and lung adenocarcinomas as well as HCC. Therefore, the patient in this case report, with advanced multiple HCCs with portal vein tumor thrombi, was treated with $\mathrm{UFT}^{\mathbb{R}}$. As a result, this patient showed marked tumor regression without side effects and had a good prognosis.

Recently, $\mathrm{UFT}^{\circledR}$ has received considerable attention as
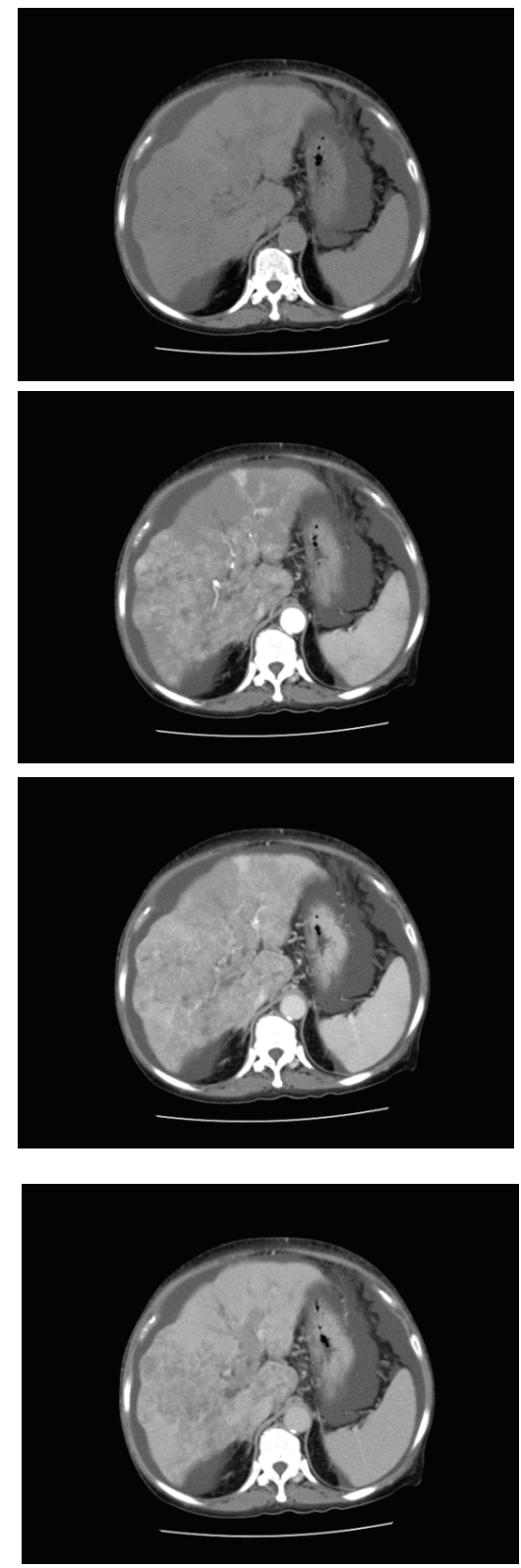

Figure 1. A large mass occupies the entire liver and tumor thrombi are apparent in main portal vein. Moderate ascited is detected. 
Table 1. Laboratory data on admission.

\begin{tabular}{llll}
\hline WBC & $8800 / \mathrm{ul}$ & BS & $141 \mathrm{mg} / \mathrm{dl}$ \\
\hline Neutro & $60.9 \%$ & $\mathrm{CRP}$ & $2.52 \mathrm{mg} / \mathrm{dl}$ \\
Eosin & $3.6 \%$ & $\mathrm{Na}$ & $139 \mathrm{mEq} / \mathrm{L}$ \\
Baso & $0.5 \%$ & $\mathrm{k}$ & $3.6 \mathrm{mEq} / \mathrm{L}$ \\
Mono & $9.1 \%$ & $\mathrm{CI}$ & $99 \mathrm{mEq} / \mathrm{L}$ \\
Lympho & $25.9 \%$ & & \\
RBC & $508 \times 10^{4} / \mathrm{ul}$ & & $317.2 \mathrm{ng} / \mathrm{ml}$ \\
$\mathrm{Hb}$ & $16.1 \mathrm{~g} / \mathrm{dl}$ & $162210 \mathrm{Mau} / \mathrm{ml}$ \\
$\mathrm{Ht}$ & $48.0 \%$ & AFP & \\
PIt & $15.6 \times 10^{4} / \mathrm{ul}$ & & \\
& & & \\
TP & $7.1 \mathrm{~g} / \mathrm{dl}$ & & \\
Alb & $3.2 \mathrm{~g} / \mathrm{dl}$ & & \\
BUN & $18 \mathrm{mg} / \mathrm{dl}$ & & \\
Cr & $0.7 \mathrm{mg} / \mathrm{dl}$ & & \\
T-Bil & $1.5 \mathrm{mg} / \mathrm{dl}$ & \\
D-Bil & $0.6 \mathrm{mg} / \mathrm{dl}$ & \\
AST & $122 \mathrm{IU} / \mathrm{L}$ & & \\
ALT & $39 \mathrm{IU} / \mathrm{L}$ & \\
PT $\%$ & $53.3 \%$ & \\
PT INR & $357 \mathrm{U} / \mathrm{L}$ & \\
LDH & $330 \mathrm{U} / \mathrm{L}$ & \\
$\gamma$-GTP & & & \\
\hline
\end{tabular}
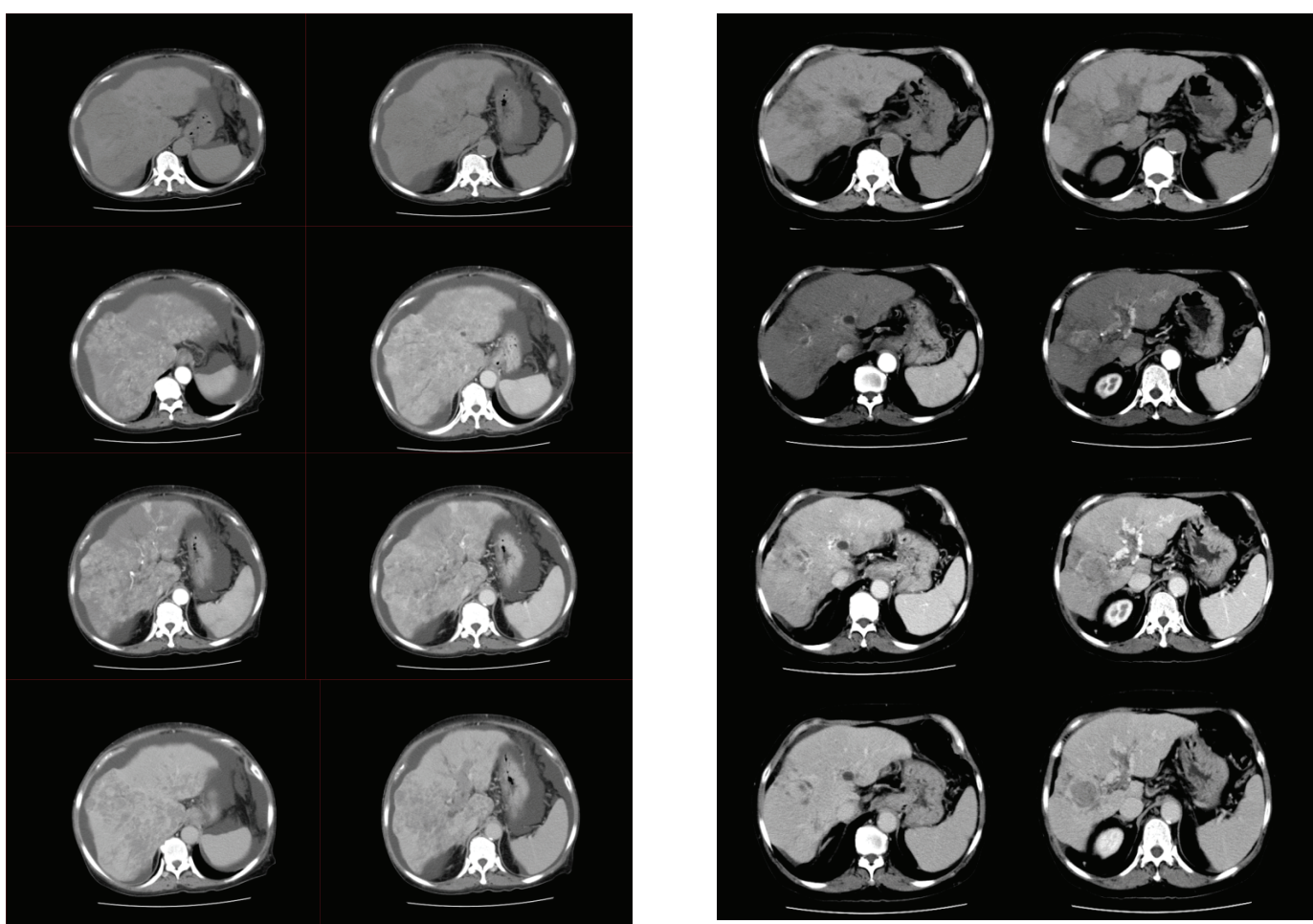

Figure 2. A large mass occupied the entire liver become smaller 8 months after treatment. Though tumor thrombi in main portal vein do not disappear, cavernous transformation by portal vein is formed. Ascites is disappeared. 
an effective anticancer therapy [9-12]. However, the effectiveness of $\mathrm{UFT}^{\mathbb{B}}$ has been controversial, as some studies have suggested that the efficacy of $\mathrm{UFT}^{\circledR}$ may have been overestimated [13].

Tegafur is slowly metabolized by mitochondrial cytochrome 450 to 5 -fluorouracil (5-FU) and the additional uracil potentiates the efficacy of tegafur by inhibiting its catabolism $[14,15]$. The mechanism of this inhibition by uracil is the blockage of dihydropyrimidine dehydrogenase (DPD) activity [16]. Therefore, rapid degradation of 5-FU by high levels of DPD activity in hepatoma cells has been implicated in 5-FU insensitivity. On the other hand, patients with low DPD activity in HCC tissues have a high concentration of 5-FU, which may have a potent anticancer effect against HCC. In this regard, Baba $\mathrm{H}$ et al. showed that some $\mathrm{HCC}$ tissues have low DPD activity and such HCC tissues may be 5-FU sensitive [17].

Recently, we showed that UFT $^{\circledR}$ administration after TACE in cases of advanced HCC was advantageous and that it contributed to the inhibition of tumor angiogenesis through vascular endothelial growth factor (VEGF) [18]. In addition, some studies have shown that UFT $^{\circledR}$ inhibits tumor angiogenesis in several cancer types. Our findings suggest that the HCC derived from the patient in this case report had low DPD activity and that tumor angiogenesis was effectively inhibited by $\mathrm{UFT}^{\circledR}$ treatment.

In conclusion, the present report demonstrates marked tumor regression and a good prognosis following oral $\mathrm{UFT}^{\circledR}$ treatment in a patient with advanced multiple HCCs with portal vein tumor thrombosis. This case strongly indicates that oral $\mathrm{UFT}^{\circledR}$ can be an effective treatment for some cases of advanced $\mathrm{HCC}$ with tumor thrombosis (VP4).

\section{REFERENCES}

[1] J. Bruix, J. M. Llovet, A. Castells, X. Montana, C. Bru, M. C. Ayuso, R. Vilana and J. Rodes, "Transarterial Embolization Versus Symptomatic Treatment in Patients with Advanced Hepatocellular Carcinoma: Results of a Randomized, Controlled Trial in a Single Institution," Hepatology, Vol. 27, No. 6, 1998, pp. 1578-1583.

[2] J. M. Llovet, M. I. Real, X. Montana, R. Planas, S. Coll, J. Aponte, C. Ayuso and M. Sala, "Arterial Embolization or Chemoembolization Versus Symptomatic Treatment in Patients with Unresectable Hepatocellular Carcinoma: A Randomized Controlled Trial," Lancet, Vol. 359, No. 9319, 2002, pp. 1734-1739.

[3] T. Livraghi, V. Benedini, S. Lazzaroni, F. Meloni, G. Torzilli and C. Vettori, "Long Term Results of Single Session Percutaneous Ethanol Injection in Patients with Large Hepatocellular Carcinoma," Cancer, Vol. 83, No. 1, 1998, pp. 48-57.
[4] R. Tateishi, S. Shiina, T. Teratani, S. Obi, S. Sato, Y. Koike, T. Fujishima, H. Yoshida, T. Kawabe and M. Omata, "Percutaneous Radiofrequency Ablation for Hepatocellular Carcinoma: An Analysis of 1000 Cases," Cancer, Vol. 103, No. 6, 2005, pp. 1201-1209.

[5] T. Yamamoto, H. Nagano, Y. Imai, K. Fukuda, H. Matsumoto, M. Kondo, H. Ota, M. Nakamura, H. Wada, T. Noda, B. Damdinsuren, K. Dono, K. Umeshita, S. Nakamori, M. Sakon, K. Wakasa and M. Monden, "Successful Treatment of Multiple Hepatocellular Carcinoma with Tumor Thrombi in the Major Portal Branches by Intraarterial 5-Fluorouracil Perfusion Chemotherapy Combined with Subcutaneous Interferon-Alpha and Hepatectomy," International Journal of Clinical Oncology, Vol. 12, No. 2, 2007, pp. 150-154.

[6] M. Sakon, H. Nagano, K. Dono, S. Nakamori, K. Umeshita, A. Yamada, S. Kawata, Y. Imai, S. Iijima and M. Monden, "Combined Intraarterial 5-Fluorouracil and Subcutaneous Interferon-Alpha Therapy for Advanced Hepatocellular Carcinoma with Tumor Thrombi in the Major Portal Branches," Cancer, Vol. 94, No. 2, 2002, pp. 435-442.

[7] M. Akamatsu, H. Yoshida, S. Obi, S. Sato, Y. Koike, T. Fujishima, R. Tateishi, M. Imamura, K. Hamamura, T. Teratani, S. Shiina, T. Ishikawa and M. Omata, "Evaluation of Transcatheter Arterial Embolization Proir to Percutaneous Tumor Ablation in Patients with Hepatocellular Carcinoma: A Randomized Controlled Trial," Liver International, Vol. 24, No. 6, 2004, pp. 625-629.

[8] K. Ohmoto, N. Yoshioka, Y. Tomiyama, N. Shibata, T. Kawase, K. Yoshida, M. Kuboki and S. Yamamoto, "Comparison of Therapeutic Effects between Radio-frequency Ablation and Percutaneous Microwave Coagulation Therapy for Small Hepatocellular Carcinomas," Journal of Gastroenterology and Hepatology, Vol. 24, No. 2, 2008, pp. 223-227.

[9] J. Felieu, M. Gonzalez Baron, E. Espinosa, C. Garcia Giron, I. de la Gandara, J. Espinosa, A. Colmenarejo, J. I. Jalon, Y. Femandez and J. de Castro, "Uracil and Tegafur Modulated with Leucovorin; an Effective Regimen with Low Toxicity for the Treatment of Colorectal Carcinoma in the Elderly," Cancer, Vol. 79, No. 10, 1997, pp. 18841889.

[10] H. Kato, Y. Ichinose, M. Ohta, E. Hata, N. Tsubota, H. Tada, Y. Watanabe, H. Wada, M. Tsuboi, J. Hamajima and M. Ohta, "A Randomized Trial of Adjuvant Chemotherapy with Uracil-Tegafur for Adenocarcinoma of the Lung," The New England Journal of Medicine, Vol. 350, No. 17, 2004, pp. 1713-1721.

[11] M. Yamamoto, S. Arii, K. Sugihara and T. Tobe, "Adjuvant Oral Chemotherapy to Prevent Recurrence after Curative Recection for Hepatocellular Carcinoma," British Journal of Surgery, Vol. 83, No. 3, 1996, pp. 336-340.

[12] T. Ishikawa, T. Ichida, Y. Ishimoto, J. Yokoyama, M. Nomoto, Y. Ebe, et al., "Complete Remission of Multiple Hepatocellular Carcinomas Associated with Hepatitis C Virus-Related, Decompensated Liver Cirrhosis by Oral 
Administration of Enteric-Coated Tegafur/Uracil," The American Journal of Gastroenterology, Vol. 94, No. 6, 1999, pp. 1682-1685.

[13] K. Hasegawa, T. Takayama, M. Ijichi, Y. Matsuyama, H. Imamura, K. Sano, Y. Sugawara, N. Kokudo and M. Makuuchi, "Uracil-Tegafur as an Adjuvant for Hepatocellular Carcinoma: A Randomized Trial," Hepatology, Vol. 44, No. 4, 2006, pp. 891-895.

[14] O. Nakajima, K. Ihara, T. Isoda, Y. Takemasa, Y. Imamura and Y. Koyama, "Phase I and Phase II Studies on a Mixture of 1-(2-Tetrahydrofulyl)-5-Fluorouracil and Uracil (UFT)," Japanese Journal of Cancer and Chemotherapy, Vol. 7, 1980, pp. 1558-1568.

[15] Y. M. Rustum, "Mechanism-Based Improvement in the Therapeutic Selectivity of 5-FU Prodrug Alone and under Conditions of Metabolic Modulation," Oncology, Vol. 54, No. (Suppl. 1), 1997, pp. 7-11.
[16] A. Lee, H. Ezzeldin, J. Fourie and R. Diasio, "Dihydropyrimidine Dehydrgenase Deficiency: Impact of Pharmacogenetics on 5-Fluorouracil Therapy," Clinical Advances in Hematology and Oncology, Vol. 2, No. 8, 2004, pp. 527-532.

[17] H. Baba, K. Teramoto, T. Kawamura, A. Mori, M. Imamura and S. Arii, "Dihydropyrimidine Dehydrogenase and Thymidylate Synthase Activities in Hepatocellular Carcinomas and in Deseased Livers," Cancer Chemotherapy and Pharmacology, Vol. 52, No. 6, 2003, pp. 469-476.

[18] H. Ueda, H. Tanaka, Y. Kida, H. Fukuchi and M. Ichinose, "Adjuvant Chemotherapy with Tegafur/Uracil Administration after Transcatheter Arterial Chemoembolization for Advanced Hepatocellular Carcinoma," Oncology Reports, Vol. 19, No. 5, 2008, pp. 1355-1361. 